\title{
Effects of Deposition of Dam Sediments on Arable Soil
}

\author{
Veronika Řezáčová*, Pavla Kratěnová, Hedvika Kosárová
}

Institute of Chemistry and Technology of Environmental Protection, Faculty of Chemistry, Brno University of Technology, Purkyňova 118, 61200 Brno, Czech Republic

Received: January 29, 2015

Accepted: September 15, 2015

\begin{abstract}
The content of metals in soils is an indicator for assessing soil quality. Many procedures are available for determining metals in soils. The risk assessment of metals in soils is set down in legislation of the Czech Republic, in leaching by $2 \mathrm{~mol} / \mathrm{L}$ nitric acid. The decree also sets the rules of evaluation of the quality of sediments scattered across the nearby fields during the revitalization of the dam.

Sediments from Luhačovice dam were deposited on nearby fields. The contents of $\mathrm{Cd}, \mathrm{Cu}, \mathrm{Hg}, \mathrm{Ni}$, and $\mathrm{Pb}$ were determined in mixed samples. The content was determined using AAS methods. Mercury was determined directly in soil samples using CV AAS. The other metals were determined by F AAS and ET AAS in leachate by $2 \mathrm{~mol} / \mathrm{L}$ nitric acid.

The contents of $\mathrm{Cd}, \mathrm{Cu}, \mathrm{Hg}$, and $\mathrm{Pb}$ comply with the limit given by the legislative norm. However, the content of $\mathrm{Ni}$ exceeded the limits in all three sets of samples.

Therefore, the leachates by $0.05 \mathrm{~mol} / \mathrm{L}$ ethylenediaminetetraacetic acid and $1 \mathrm{~mol} / \mathrm{L}$ ammonium nitrate were analysed. These additional analyses showed the content of these forms of Ni lower by an order of magnitude, therefore $\mathrm{Ni}$ is not of significant risk.
\end{abstract}

Keywords: metals, soil, sediment, AAS

\section{Introduction}

Soil is the upper layer of the Earth's structure. It is a unique mixture of mineral components, dead organic matter, and living organisms, and is vital and irreplaceable for human life and all other living organisms [1]. The function of soil is disrupted mainly due to anthropogenic activities $[2,3]$.

Sediment is a naturally occurring material that is broken down by processes of weathering and erosion and is subsequently transported by the actions of wind, water, and ice, and or by the force of gravity acting on the particle itself [4]. The sediment formations related to water occur to a full extent in aquatic ecosystems: in headwaters areas, along

*e-mail: rezacova@fch.vutbr.cz riverbanks, and in other sources of water flow like deltas, lakes, and seas. The sediment particles settle on the bottoms of river basins and sedimentation tanks, where the flow of water is slow [5]. The sediment acts as a potential reservoir of many risk elements, especially in the areas affected by civilization. Also, the high incidence of cyanobacteria is the cause of long-term low-quality water in summer months. This may be an argument for cleaning the affected waters by removing unwanted anthropogenic sediments [6].

A specific example of this procedure is analysed in this article. Luhačovice is the well-known Moravian spa (Czech Republic) with a long tradition of therapy of breathing pathways, metabolic diseases, or diabetes. Luhačovice mineral water, good natural conditions, interesting surroundings, and typical architecture are the main attractions for visitors [7]. The Luhačovice Dam Reservoir, completed in 1930, 
has a capacity of 2.7 million $\mathrm{m}^{3}$. It is used to regulate the flow of the Št'ávnice River, to produce electricity, and for recreational purposes [8]. The cleaning of the dam began in September 2010. It was necessary to remove $295,000 \mathrm{~m}^{3}$ of sediment with a high content of nutrients.

An authorization permitting storage of part of the sediment was issued by authorities. However, the rules for proper disposal of sediments were not observed, particularly the height of the deposited layer, and therefore the sediment had to be removed later from some parcels of land.

Various methods are used in order to determine the content of metals in soils. For example, it is possible to perform analysis of a solid sample by means of neutron activation analysis, mass spectrometry, and x-ray fluorescence analysis $[9,10]$. Methods based on atomic absorption and emission spectrometry are commonly used [10-20].

A sample of soil must be treated for determination of metals with respect to selected analytical spectrometric methods. One option is total analysis, in which case the concentration of metals is determined in a solution after decomposition of the sample by the mixture of acids $(\mathrm{HCl}$, $\mathrm{HNO}_{3}$, and $\mathrm{HF}$ ).

The most commonly used method is the extraction (or leaching) of solid samples. The amount of released met- als depends on the choice of extraction agent. Commonly used extraction agents are solutions of salts, acids, and chelating agents. This procedure allows determination of the elements that can be mobilized by changing soil conditions. The extraction can be performed in a single step or as a sequential method. This type of extraction is used, for example, in order to determine the amount of metals available to plants or those that can migrate in soils. The sequential extraction method is a sequence of extractions, through which are released forms of metals bounded in the different phases of the sample matrix [21-24].

The aim of this study was to evaluate whether the application of sediment and other associated processes could increase the occurrence of observed risk metals $(\mathrm{Cd}, \mathrm{Cu}$, $\mathrm{Hg}, \mathrm{Ni}$, and $\mathrm{Pb}$ ) in the location.

\section{Material and Methods}

All solutions of metals standards were prepared from standard calibration solutions of $\mathrm{Cd}, \mathrm{Cu}, \mathrm{Hg}, \mathrm{Ni}$, and $\mathrm{Pb}$ $1.000 \pm 0.002 \mathrm{~g} / \mathrm{L}$ (Analytika, Prague, Czech Republic) diluted by MiliQ water to the required concentrations. 65\% nitric acid, p. a. (Analytika, Praque, Czech Republic);

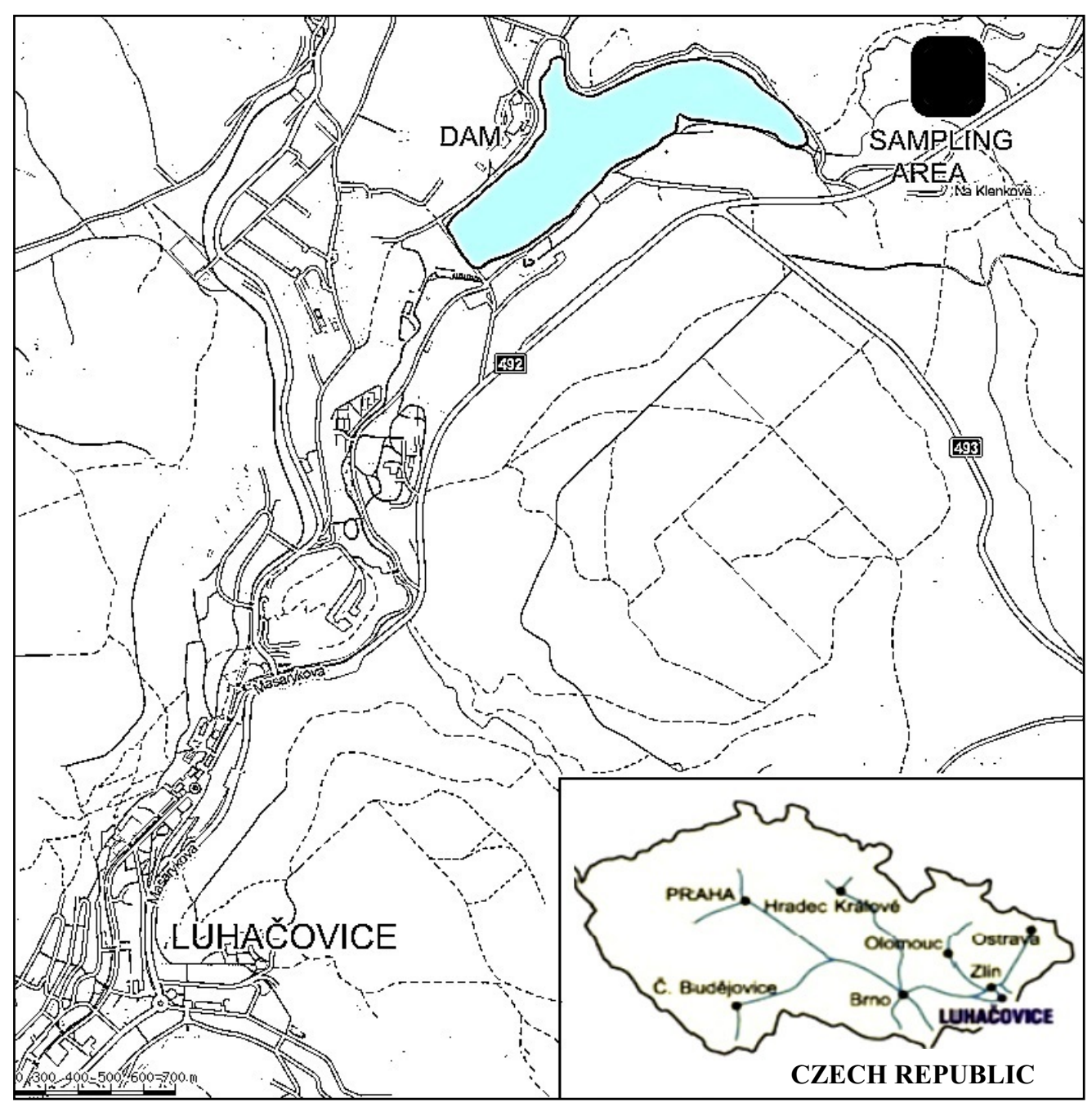

Fig. 1. Map of the area of interest. 
Table 1. Instrumental parameters for determination of $\mathrm{Hg}$ directly in samples using AMA 254.

\begin{tabular}{|l|c|c|c|}
\hline & Drying [s] & Decomposition [s] & Waiting [s] \\
\hline Cleaning & 60 & 120 & 45 \\
\hline Blank & 60 & 60 & 45 \\
\hline Calibration & 60 & 120 & 45 \\
\hline Sample & 10 & 200 & 50 \\
\hline
\end{tabular}

ammonium nitrate, p. a. (Penta, Praque, Czech Republic); and ethylenediaminetetraacetic acid, p.a. (Lachema, Brno, Czech Republic) were used as leaching agents after appropriate dilution.

An AMA-254 spectrometer (Altec, Czech Republic) was used to determine $\mathrm{Hg}$. A SpectrAA 30 flame atomic absorption spectrometer (Varian, France) and ZEEnit 60 atomic absorption spectrometer with graphite furnaceequipped Zeeman background correction (Analytik Jena, Germany) were used to determine $\mathrm{Cd}, \mathrm{Cu}, \mathrm{Ni}$, and $\mathrm{Pb}$ contents.

Oxygen, acetylene, and argon needed for measurements were supplied by Siad, Czech Republic.

The samples were taken from parcel 2707/1 ROVINA, an area of 5.4 hectares in Dolní Lhota by Luhačovice, in April 2013 (Fig. 1). The first set consisted of four samples (1A-1D) of the soil from an area on which sediment had not been deposited. The second set was made up of four samples of soil (2A-2D) from the area where the sediment was stored. The third set consisted of four samples (3A-3D) taken from the area where the sediment had been temporarily deposited.

The content of dry matter in the samples was determined by drying at $95^{\circ} \mathrm{C}$ to constant weight.

The extractions procedures adopted from [22] and [25] were carried out as follows:

- Leaching of soil samples by $2 \mathrm{~mol} / \mathrm{L} \mathrm{HNO}_{3}: 5 \mathrm{~g}$ of sample was mixed with $50 \mathrm{~mL}$ of the extraction agent in a bottle, shaken for $120 \mathrm{~min}$ and filtered

- Leaching of soil samples by $0.05 \mathrm{~mol} / \mathrm{L}$ EDTA: $5 \mathrm{~g}$ of sample was mixed with $50 \mathrm{~mL}$ of the extraction agent in a bottle, shaken for $90 \mathrm{~min}$, filtered

- Leaching of soil samples by $1 \mathrm{~mol} / \mathrm{L} \mathrm{NH}_{4} \mathrm{NO}_{3}: 20 \mathrm{~g}$ of sample was mixed with $50 \mathrm{~mL}$ of the extraction agent in a bottle, shaken for $120 \mathrm{~min}$, filtered

Mercury was determined directly in soil samples by $\mathrm{CV}$ AAS using AMA 254; $200 \mu \mathrm{g}$ of soil samples were analyzed (measurement parameters are in Table 1).

Leachates were used to determine $\mathrm{Cu}, \mathrm{Ni}$, and $\mathrm{Pb}$ in 2 mol/L $\mathrm{HNO}_{3} \mathrm{~F} \mathrm{AAS} \mathrm{(SpectrAA} \mathrm{30,} \mathrm{Varian).} \mathrm{Experimental}$ parameters are summarized in Table 2.

The determination of $\mathrm{Cd}$ in $2 \mathrm{~mol} / \mathrm{L} \mathrm{HNO}_{3}$ leachates and determination of $\mathrm{Ni}$ in $0.05 \mathrm{~mol} / \mathrm{L}$ EDTA leachates and $1 \mathrm{~mol} / \mathrm{L} \mathrm{NH}_{4} \mathrm{NO}_{3}$ leachates were performed by ET AAS (ZEEnit 60, Analytic Jena) without modifiers under recommended conditions. Experimental parameters are summarized in Table 3.
Table 2. Instrumental parameters for determining $\mathrm{Cu}, \mathrm{Ni}$, and $\mathrm{Pb}$ in leachates by $2 \mathrm{~mol} / \mathrm{L} \mathrm{HNO}_{3}$.

\begin{tabular}{|l|c|c|c|}
\hline & $\mathrm{Cu}$ & $\mathrm{Ni}$ & $\mathrm{Pb}$ \\
\hline Wavelength [nm] & 324.8 & 232 & 217 \\
\hline Band width [nm] & 0.5 & 0.2 & 1 \\
\hline Lamp current [mA] & 10 & 15 & 10 \\
\hline Airflow rate [L/min] & 3.5 & 3.5 & 3.5 \\
\hline Acetylene flow rate [L/min] & 1.5 & 1.5 & 1,5 \\
\hline Read time [s] & 10 & 10 & 10 \\
\hline Calibration range [mg/L] & $0-5$ & $0-10$ & $0-5$ \\
\hline LOD [mg/L] & 0.07 & 0.08 & 0.38 \\
\hline
\end{tabular}

Table 3. Instrumental parameters for determining $\mathrm{Cd}$ in leachates by $2 \mathrm{~mol} / \mathrm{L} \mathrm{HNO}_{3}$ and determining $\mathrm{Ni}$ in leachates by $0.05 \mathrm{~mol} / \mathrm{L}$ EDTA and $1 \mathrm{~mol} / \mathrm{L} \mathrm{NH}_{4} \mathrm{NO}_{3}$.

\begin{tabular}{|l|c|c|}
\hline & $\mathrm{Cd}$ & $\mathrm{Ni}$ \\
\hline Wavelength [nm] & 228.8 & 232 \\
\hline Band width [nm] & 0.8 & 0.5 \\
\hline HCL current [mA] & 3 & 6 \\
\hline $\begin{array}{l}\text { Temperature } \\
\text { programe: }\end{array}$ & $\begin{array}{c}\text { drying: } 105+120 \\
5 / 20+2 / 20\end{array}$ & $\begin{array}{c}\text { drying: } 105+120 \\
5 / 20+2 / 20\end{array}$ \\
\hline Temperature $\left[{ }^{\circ} \mathrm{C}\right]$ & $\begin{array}{c}\text { pyrolysis: } 500 \\
25 / 30\end{array}$ & $\begin{array}{c}\text { pyrolysis: } 900 \\
25 / 30\end{array}$ \\
\hline Time [s]: Ramp/Hold & \begin{tabular}{c} 
atomization: 1500 \\
\cline { 2 - 3 }
\end{tabular} & $\begin{array}{c}\text { atomization: } 2300 \\
0 / 5\end{array}$ \\
\cline { 2 - 4 } & $1 / 3$ & $\begin{array}{c}\text { clean out: } 2350 \\
1 / 3\end{array}$ \\
\hline $\begin{array}{l}\text { Calibration range } \\
{[\mathrm{mg} / \mathrm{L}]}\end{array}$ & $0-5$ & $0-200$ \\
\hline LOD [mg/L] & 0.4 & 1.5 \\
\hline Injection volume [mL] & 20 & 20 \\
\hline
\end{tabular}

\section{Results}

In this work, extraction by $2 \mathrm{~mol} / \mathrm{L} \mathrm{HNO}_{3}$ for the determination of $\mathrm{Cd}, \mathrm{Cu}, \mathrm{Ni}$, and $\mathrm{Pb}$ in soil and sediment samples was selected, because of the possibility of comparing the found contents of metals with the maximum permissible contents specified in the Decree of the Ministry of Agriculture and Ministry of the Environment of the Czech Republic No. 257/2009 Coll. [26]. In addition, $0.05 \mathrm{~mol} / \mathrm{L}$ ethylenediaminetetraacetic acid (EDTA) and $1 \mathrm{~mol} / \mathrm{L}$ $\mathrm{NH}_{4} \mathrm{NO}_{3}$ were used to determine $\mathrm{Ni}$.

In order to determine mercury we used a dedicated AMA-254 analyzer (Advanced Mercury Analyser) that operates on the principle of cold vapour atomic absorption spectrometry (CV AAS). 
The results of determination of heavy metals $(\mathrm{Cd}, \mathrm{Cu}$, $\mathrm{Hg}, \mathrm{Ni}, \mathrm{Pb}$ ) in the three sets of samples taken from:

1) original arable soil

2) applied sediment

3) soil after removing temporarily deposited sediment are shown in Figs. 2-6.

The columns denote the contents of $\mathrm{Hg}$ obtained by direct analysis of the soil samples and the contents of $\mathrm{Cd}$,

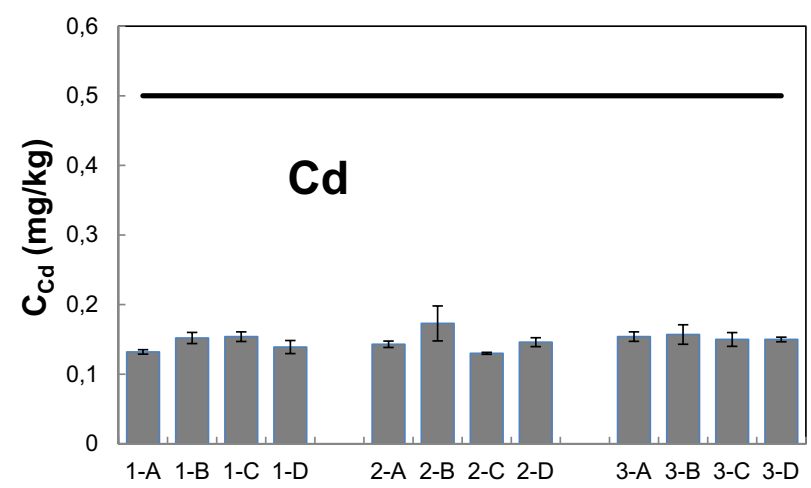

Fig. 2. Results of the determination of $\mathrm{Cd}$ in leachates by 2 $\mathrm{mol} / \mathrm{L} \mathrm{HNO}_{3}$ (columns) compared to the maximum permissible content of $\mathrm{Cd}$ as set by the decree (line).

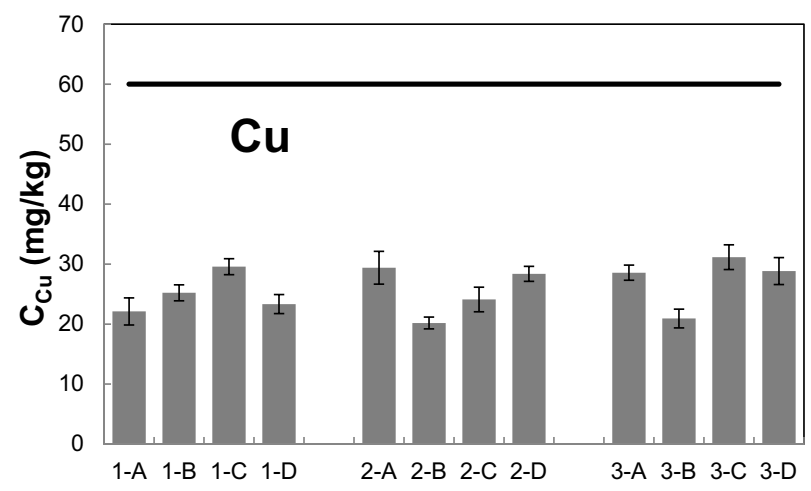

Fig. 3. Results of the determination of $\mathrm{Cu}$ in leachates by 2 $\mathrm{mol} / \mathrm{L} \mathrm{HNO}_{3}$ (columns) compared to the maximum permissible content of $\mathrm{Cu}$ as set by the decree (line).

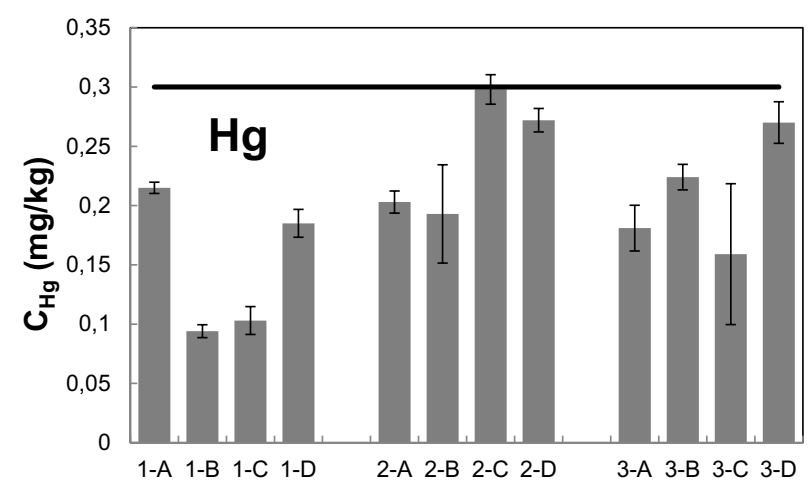

Fig. 4. Results of the determination of Hg (columns) compared to the maximum permissible content of $\mathrm{Hg}$ as set by the decree (line).

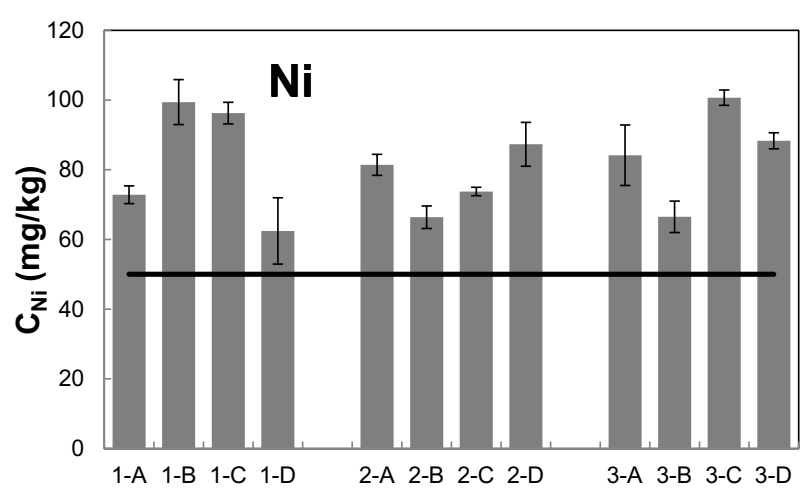

Fig. 5. Results of the determination of $\mathrm{Ni}$ in leachates by 2 $\mathrm{mol} / \mathrm{L} \mathrm{HNO}_{3}$ (columns) compared to the maximum permissible content of $\mathrm{Ni}$ as set by the decree (line).

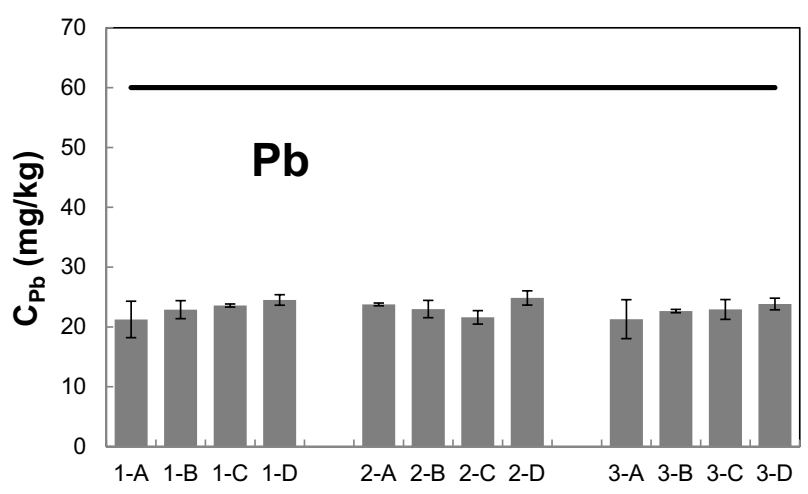

Fig. 6. Results of the determination of $\mathrm{Pb}$ in leachates by 2 $\mathrm{mol} / \mathrm{L} \mathrm{HNO}_{3}$ (columns) compared to the maximum permissible content of $\mathrm{Pb}$ as set by the decree (line).

$\mathrm{Cu}, \mathrm{Ni}$, and $\mathrm{Pb}$ in $2 \mathrm{~mol} / \mathrm{L} \mathrm{HNO}_{3}$ leachates. The line shows the maximum permissible content of metals set by Decree No. 257/2009 Coll.

The content of cadmium found in the samples in $2 \mathrm{~mol} / \mathrm{L}$ $\mathrm{HNO}_{3}$ is within the range of $(0.1-0.2) \mathrm{mg} / \mathrm{kg}$ of dry matter. It complies with the maximum permissible content of $\mathrm{Cd}$ given by the decree for heavy metals in the sediment applied to cropland $(0.5 \mathrm{mg} / \mathrm{kg})$. The highest $\mathrm{Cd}$ content was determined in sample No. 2-B and was found to be $0.17 \mathrm{mg} / \mathrm{kg}$ of dry matter. The lowest value of $0.13 \mathrm{mg} / \mathrm{kg}$ dry matter was found in sample No. 2-C. Both samples (2B, 2C) were taken from the area where the sediment was deposited.

The determined amount of copper ranges from 20.2 to $31.2 \mathrm{mg} / \mathrm{kg}$ of dry matter. Thus, all the samples comply with the maximum permissible content of $\mathrm{Cu}(60 \mathrm{mg} / \mathrm{kg})$ set by decree No. 257/2009 Coll., which established the rules of application of sediments on agricultural land.

The content of mercury determined by direct analysis of solid samples ranged from 0.103 to $0.298 \mathrm{mg} / \mathrm{kg}$ of dry matter. All the samples comply with the maximum permissible content of $\mathrm{Hg}$ given in Decree No. 257/2009 Coll. (0.3 $\mathrm{mg} / \mathrm{kg}$ ). The lowest values of mercury 0.094 and 0.103 $\mathrm{mg} / \mathrm{kg}$ of dry matter were determined in sample Nos. 1-B and 1-C. These samples were taken from an area where sediment had not been deposited. The highest results were 
found in sample Nos. 2-C and 2-D and contained 0.298 and $0.272 \mathrm{mg} / \mathrm{kg}$ of dry matter. These samples were taken from the area where the sediment had been applied. An increased amount of mercury $(0.270 \mathrm{mg} / \mathrm{kg})$ was also determined in sample No. 3-D taken in the area, from which the deposited sediment had to be removed.

The content of lead determined in the leachates by 2 $\mathrm{mol} / \mathrm{L}_{\mathrm{HNO}_{3}}$ does not exceed the maximum permissible content of Pb set by Decree No. 257/2009 Coll. (60 mg/kg). The amount of lead ranges in a relatively narrow range from 21.25 to $24.85 \mathrm{mg} / \mathrm{kg}$ of dry matter.

The content of nickel in the analysed soils significantly exceeds the maximum permissible content of $\mathrm{Ni}$ set by Decree No. 257/2009 Coll. (50 mg/kg). The average amount of nickel in the samples was $81.6 \mathrm{mg} / \mathrm{kg}$ of dry matter. The highest values 100.69 and $99.41 \mathrm{mg} / \mathrm{kg}$ were found in sample Nos. 1-B and 3-C. One of the samples was taken from the area on which sediment had not been applied, the other was taken from the soil after removing of the deposited sediment. The lowest value was observed in sample No. 1-D taken from soil unaffected by sediment. There we found $62.44 \mathrm{mg} / \mathrm{kg}$ of dry matter. Even this lowest value exceeds the legal limit content. The determined content of $\mathrm{Ni}$ exceeds the maximum permissible content in all three sets of samples, probably because of geogenic origin.

Because of the high contents of $\mathrm{Ni}$ determined in leachates by $2 \mathrm{~mol} / \mathrm{L} \mathrm{HNO}_{3}$, the samples were extracted by $0.05 \mathrm{~mol} / \mathrm{L}$ EDTA and $1 \mathrm{~mol} / \mathrm{L} \mathrm{NH}_{4} \mathrm{NO}_{3}$ for further assessment of available and bioavailable forms of Ni. These leachates were analysed by ET AAS. The results show that the contents of these Ni-forms are several times lower than the overall content of $\mathrm{Ni}$ in $2 \mathrm{~mol} / \mathrm{L} \mathrm{HNO}_{3}$ leachates (Fig. 7). The EDTA-extractable content of nickel ranged from 0.18 to $0.36 \mathrm{mg} / \mathrm{kg}$ of dry matter. The average value $0.24 \mathrm{mg} / \mathrm{kg}$ is only $0.3 \%$ of the average Ni content found in the extract by $2 \mathrm{~mol} / \mathrm{L} \mathrm{HNO}_{3}$. In the leachate by $1 \mathrm{~mol} / \mathrm{L}$ $\mathrm{NH}_{4} \mathrm{NO}_{3}$, the content of nickel was determined in the range from 0.062 to $0.107 \mathrm{mg} / \mathrm{kg}$ of dry matter. The average value $0.082 \mathrm{mg} / \mathrm{kg}$ is about three orders of magnitude lower than the content found in the extract by $2 \mathrm{~mol} / \mathrm{L} \mathrm{HNO}_{3}$. These results show that the $\mathrm{Ni}$ content in the bio/available forms is very low, so that most of the nickel is bound in a matrix and should not affect the environment.

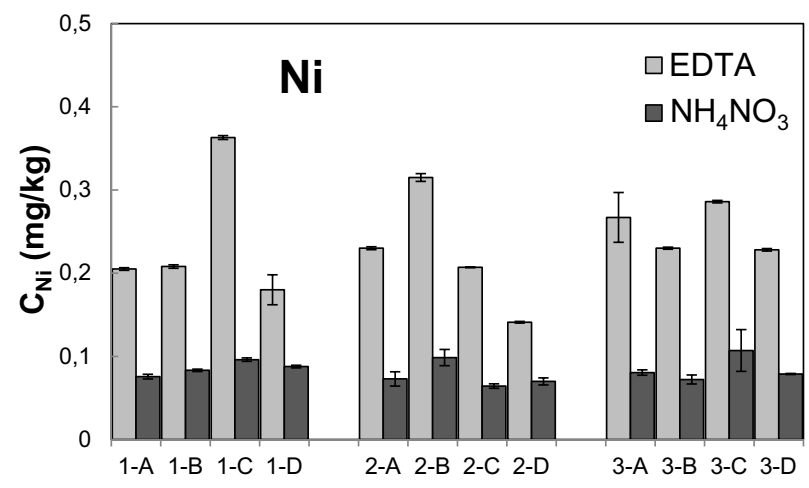

Fig. 7. Results of the determination of $\mathrm{Ni}$ in leachates by 0.05 $\mathrm{mol} / \mathrm{L}$ EDTA and $1 \mathrm{~mol} / \mathrm{L} \mathrm{NH}_{4} \mathrm{NO}_{3}$.

\section{Conclusion}

The contents of $\mathrm{Cd}, \mathrm{Cu}, \mathrm{Hg}$, and $\mathrm{Pb}$ in leachates by 2 $\mathrm{mol} / \mathrm{L} \mathrm{HNO}_{3}$ complied with the maximum permissible content of elements given by Decree No. 257/2009 Coll. for heavy metals in the sediment applied to cropland. However, the content of $\mathrm{Ni}$ exceeded the limits in all three sets of samples, probably because of geogenic origin. Therefore, the leachates by $0.05 \mathrm{~mol} / \mathrm{L}$ EDTA and $1 \mathrm{~mol} / \mathrm{L} \mathrm{NH}_{4} \mathrm{NO}_{3}$ for determining bioavailable forms of $\mathrm{Ni}$ were analysed. These additional analyses showed the content of these forms of $\mathrm{Ni}$ lower even by an order of magnitude.

The analyses show that content of studied metals in the soil was not affected by deposition of sediment taken from Luhačovice Dam Reservoir. The root of the problem of removing of sediments was the mixture of organic animal remnants and overall thickness of the layer of deposited sediment disposed of without authorization. Further study of a larger area should follow, focusing on fertility and content of hazardous elements in plants in this area.

\section{Acknowledgements}

This work was supported by grant No. FCH-S-15-2869 from the Ministry of Education, Youth, and Sports of the Czech Republic.

\section{References}

1. BOHN H.L., MYER R.A., O'CONNOR G.A. Soil Chemistry, $3^{\text {rd }}$ Edition; Wiley: New York, 2001.

2. JENSEN J., PEDERSEN M.B. Ecological risk assessment of contaminated soil. Rev. Environ. Contam. T. 186, 73, 2006.

3. KABATA-PENDIAS A. Trace Elements in Soils and Plants, $4^{\text {th }}$ Edition; Taylor\&Francis: Boca Raton, 2011.

4. PROTHERO D.R., SCHWAB F. Sedimentary Geology; W.H.Freeman \& Co: New York, 1996.

5. BRILS J. Sediment monitoring and the European Water Framework Directive. Annali dell'Istituto Superiore di Sanità 44, (3), 218, 2008.

6. SVIRČEV Z.B., TOKODI N., DRABAC D., CODD G.A. Cyanobacteria in aquatic ecosystems in Serbia: Effects on water quality, human health and biodiversity. Syst. Biodivers. 12, (3), 261, 2014.

7. Official guide of the spa town [online] 13.01.2015 Available at http://www.luhacovice.cz/en/

8. Luhačovice reservoir dam and its surroundings were completely reconstructed, In: Luhačovice: Official guide of the spa town [online] 13.03.2013 Available at:

http://www.luhacovice.cz/26294n-luhacovicka-nadrz-proslai-s-okolim-kompletni-rekonstrukci [In Czech].

9. LU X., WANG L., LEI K., HUANG J., ZHAI Y. Comtamination assessment of copper, lead, zinc, manganase and nickel in street dust of Baoji, NW China. J. Hazard. Mater. 161, 1058, 2009.

10. WEI B., YANG L. A review of heavy metal contaminations in urban soils, urban road dusts and agricultural soils from China. Microchem. J. 94, 99, 2010.

11. DEAN J.R. Methods for environmental trace analysis; Wiley: New York, 2003. 
12. HUANG H., YUAN X., ZENG G., ZHU H., LI H., LIU Z., JIANG H., LENG L., BI W. Quantitative evaluation of heavy metals pollution hazards in liquefaction residues of sewage sludge. Bioresource Technol. 102, 10346, 2011.

13. KARA D., FISHER A., HILL S.J. Determination of trace heavy metals in soil and sediments by atomic spectrometry following preconcentration with Schiff bases on Amberlite XAD-4. J. Hazard. Mater. 165, 1165, 2009.

14. DUONG T.T.T., LEE B.-K. Determining contamination level of heavy metals in road dust from busy traffic areas with different characteristics. J. Environ. Manage. 92, 554, 2011.

15. JAMALI M.K., KAZI T.G., ARAIN M.B., AFRIDI H.I., JALBANI N., KANDHRO G.A., SHAH A.Q., BAIG J.A. Speciation of heavy metals in untreated sewage sludge by microwave assisted sequential extraction procedure. J. Hazard. Mater. 163, 1157, 2009.

16. FAIZ Y., TUFAIL M., TAYYEB JAVED M., CHAUDHRY M.M., SIDDIQUE N. Road dust pollution of $\mathrm{Cd}, \mathrm{Cu}, \mathrm{Ni}, \mathrm{Pb}$ and $\mathrm{Zn}$ along Islamabad Expressway, Pakistan. Microchem. J. 92, 186, 2009.

17. CHRISTOFORIDIS A., STAMATIS N. Heavy metal contamination on street dust and roadside soil along the major national road in Kavala's region, Greece. Geoderma 151, 257, 2009.

18. ONDER S., DURSUN S., GEZGIN S., DEMIRBAS A. Determination of heavy metal pollution in grass and soil of city centre green areas (Konya, Turkey). Pol. J. Environ. Stud. 16, (1), 145, 2007.

19. CAPPUYNS V., SWENNEN R. The use of leaching tests to study the potential mobilization of heavy metals from soils and sediments: A comparison. Water Air Soil Poll. 191, 95, 2008.

20. REMON E., BOUCHARDON J.L., CORNIER B., GUY B., LECLERC J.C., FAURE O. Soil characteristics, heavy metal availability and vegetation recovery at a former metallurgical landfill: Implications in risk assessment and site restoration. Environ. Pollut. 137, 316, 2005.

21. RAURET G. Extraction procedures for determination of heavy metals in contaminated soil and sediment. Talanta 46, 449, 1998.

22. URE A.M., QUEVAUVILleR PH., MUNTAU H., GRIEPINK B. Speciation of heavy metals in soilds and harmonization of extraction techniques undertaken under the auspices of the BCR of the Commission of the European Comminuties. Int. J. Environ. An. Ch. 51, 135, 1993.

23. PEIJNENBURG W.J., ZABLOTSKAJA M., VIJVER M.G. Monitoring metals in terrestrial environments within a bioavailability framework and a focus on soil extraction. Ecotox. Environ. Safe. 67, 163, 2007.

24. GESTEL C.A.M. Physico-chemical and biological parameters determine metal bioavailability in soils. Sci. Total Environ. 406, 385, 2008.

25. ZBÍRAL J. Soil Analysis II: Standard operational procedures; Central Institute for Supervising and Testing in Agriculture: Brno, 2011 [In Czech].

26. Decree on use of sediments on agricultural soil No. 257/2009 Coll. In: Collection of Laws of the Czech Republic, 3551, 2009. Available at http://www.mvcr.cz/soubor/sb077-09-pdf.aspx [In Czech]. 